Veeran DL

\title{
COMBATING CHILD LABOUR - A SOUTH AFRICAN CHALLENGE
}

\author{
Dr DL (Vasintha) Veeran Centre for Social Work School of Psychology, University of Natal, \\ Durban.
}

Until recently child labour in South Africa received little attention from government and nongovernmental organisations (NGOs). This lack of recognition is evidenced by the dearth of research and comprehensive statistics on the extent of the problem. Although statistics have been forthcoming from the International Labour Organisation (ILO) and United Nations Children's Education Fund (UNICEF), they differ significantly on the estimates of the magnitude of child labour. The ILO estimated in 1996 that there were 120 million full-time working children ranging from 5 to 14 years. This figure is doubled when part-time working children are taken into consideration. The distribution of child labour indicates that this phenomenon is located primarily in developing countries, viz. Asia 61\%, Africa 32\% and Latin America 17\% (Grootaert \& Patrinos, 1999). Nevertheless, the highest proportion of child workers in relation to the total population is in Africa (Fyfe, 1989). Compared against global estimates, child labour in South Africa has been underestimated, contributing largely to the low-priority status it is accorded. According to the Labour Directorate there were about 200000 children working in South Africa in 1997 (Department of Labour, 1998), some as young as 5 years. Without conclusive research into the problem of child labour, it can be argued that this figure is a conservative estimate as a large percentage of "unseen" child labour is not accounted for. This includes unpaid domestic work and work in the informal sector. Other related activities that are neglected in the estimation are the increasing number of child prostitutes, largely as the result of the increasing number of street children.

International campaigns have reinforced the need for governments globally to make a concerted effort to address the problem of child labour. Several international campaigns and conferences reflect the increasing international endeavours to address the problem of child labour. The Oslo Conference on Child Labour (UNICEF, 1997) recognised and reiterated the important role that other such conferences have played in condemning the exploitation of children, without exception. This paper will provide an overview of child labour. Significant in any discussion on child labour are the determinants and efforts to eradicate it. Notwithstanding these efforts, child labour continues to be an ethical, social and economic challenge for the world. As a signatory to the United Nations Convention on the Rights of the Child (1989), South Africa has embarked on a programme through its National Programme of Action for Children, which includes the Child Labour Action Programme.

\section{DEFINITIONS AND MEASUREMENT OF CHILD LABOUR}

Part of the difficulty in arriving at realistic estimates on the extent of child labour is the controversy around definitions not only of 'child labour' but of 'child' as well. Initial campaigns against child labour in the early 1830s and 1840s were instrumental in the historic shift in thinking about the proper role of children and childhood itself. Variations in the concept of child and childhood are directly attributable to cultural and social norms, traditions and beliefs. In Western societies chronological age was a significant criterion that determined childhood, while in other societies, cultural and social factors played a significant role. Cultural determinants of children's work include gender norms and age subordination (Delap, 2001; Rodgers \& Standing, 1981). Nardinelli (1990) contended that the history of childhood has grown from humble beginnings into 
an important sub-discipline of history, sociology and anthropology. Relationships, especially between children and parents, form the basis of most studies of childhood. Some of the topics which have contributed to the history of childhood include the emotional attachment of parents to children, forms of discipline, education, health and sexual development. Added to this historical development of childhood must be the economic role of children within the family economy.

The following quotation and the following discussion make some distinctions in response to the questions: what is work, what is child and what is exploitation?

In the case of children it is relatively easy to distinguish between work at home and leisure. Housework, caring for other children, and various chores can be classified as work, whereas all those activities under the general heading of "play" can be classified as leisure. Investment in human capital, or schooling can also be classified as a form of work (Nardinelli, 1990:39).

The controversy surrounding what constitutes child labour lies not in what is work and what is play, but in the blurring of the above roles arising out of the amount of time spent on each, without due consideration of the consequences of the indeterminate allocation of time and whether this occurs within the household or external to it as well as the economic benefits. Supporting the above quotation, in that it does not reflect the intricacies associated with child work and exploitation, Rogers and Standing (1981) argued that the measurement of child work cannot be isolated from its economic and social significance. Fyfe (1989) argued that child work not only responds to economic forces, but also reflects social and cultural patterns, including power relationships between adults and children. One of the stark contrasts between developed and developing countries is the economic role of the child in the family. In industrialised (developed) countries few, if any, children work out of dire economic necessity. To put child labour into perspective, the economic approach to the history of childhood should be adopted. Nardinelli (1990) noted that child labour becomes understandable as part of the family's striving to improve its well-being. But it is difficult to make a general judgement on the overall benefit of child work without acknowledging that diverse forms of exploitation exist. Many authors agree that child labour is "work that impairs the health and development of children" (Fyfe, 1989:4), in which case, priority must be given to targeting and eradicating child prostitution, child pornography, bonded labour, work in hazardous occupations and in the military services. Extreme working conditions of children resemble slave conditions in factories, and mines, the use of dangerous chemicals in pesticide-soaked fields, in guerrilla armies and, of course, in homes as servants.

\section{RELATIONSHIP BETWEEN CHILD LABOUR LAWS AND COMPULSORY SCHOOLING}

The ILO adopted the minimum age of admission to work in industry at 14 years. Most countries which ratified the ILO Convention of 1919 either adopted the minimum age or raised the age limit, e.g. Canada set the age limit at 16. In South Africa the law prohibits employment of minors under the age of 15 (Basic Conditions of Employment Act, 1997). Compulsory education has either preceded or followed the general trend of minimum age legislation often in close correlation with the raising of the age limit for admission to work. "Schooling is universally viewed as the antidote to work", according to Fyfe (1989:8). In the absence of direct data on child labour, the relationship between child labour and non-school attendance is significant. Although school attendance is not the inverse of child labour, many children are compelled to work to meet costs of school attendance, such as, fees and books (Grootaert \& Patrinos, 1999). 
The assessment of this activity is easier said than done. Figures on school enrolment and school attendance can be misleading. In a survey in rural Chile, Rodgers and Standing (1981) found that school activity combined with other activities affected regular attendance. They found that $66 \%$ of those aged 9 to 16 attended school full time and a further $12 \%$ were engaged in full-time economic activity, but $22 \%$ combined school and work. These combinations are not necessarily incompatible; it depends on how schooling and other activities are combined and the amount of time allocated for each activity.

The state of the worlds' children with regard to education is dismal. According to UNICEF (1997), over 125 million children, mostly young girls, never see the inside of a classroom and another 150 million children receive education of such poor quality that what they learn is questionable. Propelled by these dismal statistics, the Global Campaign for Education was launched in conjunction with Education International, Oxfam International and Action Aid. The aim of the Global Campaign for Education is to mobilise public pressure on governments to fulfil their promises to provide free quality education, in particular, for children and women. The campaign advocates for at least eight years of education for all children and for adults who were deprived of educational opportunities to be given a second chance. Global factors are critical in eradicating child labour. As the stature of the problem extends beyond national boundaries, it calls for consolidated mass action that transcends these physical barriers.

\section{DETERMINANTS OF CHILD LABOUR}

The determinants of child labour can be broadly categorised into internal and external factors. Internal factors include household size, parents' educational level and participation in the labour force, gender inequalities, household's risk management and household assets. External factors involve the functioning of the labour market, production technology and the increase in the informal sector. Children are preferred over adults as a result of exploitative wage earnings, often resulting in children returning to work, while adults assume sole responsibility for household activities. Changes in technology have contributed somewhat to lower levels of child labour. Whereas primitive technologies largely encouraged the substitution of adults by children, for example, in mining, technological advancement has reversed this trend; for example, mechanisation of agriculture in Egypt has eliminated the need for children to drive animals that were water powered (Grootaert \& Patrinos, 1999). It is universally accepted that poverty remains the number one determinant of child labour and is the index of the extent of poverty (Fyfe, 1989; Meyers, 1991). This generalisation, of necessity, must include cultural and economic factors which interact in complex ways to influence child labour. The relative influence of economic and cultural factors are critical areas of debate in the discourse on household labour deployment. Data from Dhaka slums in Bangladesh suggest that income instability and household poverty are significant determinants of child labour (Delap, 2001).

The gender dimension of child labour is evident, especially in household activities. The employment of the mother is a critical determinant of child work, especially for girls (Grootaert \& Patrinos, 1999). Girls are often recruited to work in the home and to take care of younger siblings when the mother has to go out to work. The direct consequences of this are the low school enrolment rates for girls and illiteracy. In a study on the problems affecting female-headed households undertaken by Meti, Krishnaswamy and Bhat (2001), it was found that many children worked for wages and were deprived of education. This perpetuated the vicious cycle of poverty, as a consequence of illiteracy, to the next generation. 
It is important to understand the relationships that children share with their families and their communities. This provides much needed insight into the dynamics of their social contexts. Rapidly changing family forms such as single parenting, fewer kinship ties and the economic status of families are critical factors in the perpetuation of child labour. Since children's welfare are intrinsically linked to that of women, the call for the immediate implementation of the Convention on the Elimination of all forms of discrimination Against Women and the ILO Discrimination Convention, 1958 (No. 111), as well as the ratification of the ILO Equal Remuneration Convention, 1951 (No. 111) is essential.

Prevailing socio-economic conditions are the major determinants of child labour. Added to these variables is the legislative framework which prohibits child labour, albeit monitoring and enforcement are rarely implemented (Grootaerts \& Patrinos, 1999).

\section{AN INTEGRATED APPROACH TO ERADICATING CHILD LABOUR}

Preceding national and international efforts to eliminate child labour is the need for resolution of some tension between universalistic and relativistic approaches in establishing standards and strategies on the abuse of children's capacity to work. Global standards (on children's rights, unacceptable or intolerable forms of child work) should be discussed in relation to (ideal, normal or tolerable) notions of childhood, given that the definitions are themselves socially constructed and therefore specific to time, place, nation and culture (White, 1999). Over the decades concerted efforts by international agencies to curb the plight of child workers were evident.

Two recent international events namely, the Global March of 1998 and the Child Labour Convention 182 of 1999 drew attention to the urgent need for a co-ordinated international response. The Global March was the catalyst in the activities leading to the creation and adoption of Convention 182. The launch of the Global March and the momentum it gained as it proceeded consolidated the efforts of countries into strong support for action against child exploitation. Approximately 130 countries have declared their strong commitment to the goals of the Convention. The participation of children in the Global March and in the final deliberations on the text of the Convention highlighted the significance of children as partners in the process. In June 1999, the International Labour Conference unanimously adopted Convention 182 prohibiting the worst forms of child labour. It urged governments to take swift action by instituting effective measures to eliminate the most hazardous and exploitative forms of child labour practices. These included child slavery, prostitution, pornography, the use of children for drug trafficking, and the recruitment of children in armed conflict. Accompanying the Convention was Recommendation 190 that provided guidelines on specific actions to be taken by governments to ensure the implementation of Convention 182. Recommendation 190 has to be ratified by member states for it to be binding. The ratification of the United Nations Convention of the Child (1989) has been the springboard for varied initiatives highlighting the plight of children in exploitative and hazardous situations. Following the ratification of the United Nations Convention on the Rights of the Child (1989) by Mr Mandela (president at the time) on 16 June 1995, the chapter on child labour in the Basic Conditions of Employment Act, of 1997 came into effect in March 1998. This promulgation is a significant attempt to align national legislation with the South African Constitution and international standards with respect to child labour.

A more pragmatic and focused approach is required to mediate the causes and effects of child labour. An integrated programme of action involving the various role players and stakeholders holds the key to resolving the plight of child workers globally. To eliminate the reality for children to work requires a radical shift in the way child labour is conceptualised. There is consensus that the long-term integrated international effort should start with public education campaigns, which 
are insufficient in themselves (Fyfe,1989). Meyers (1991) reiterated the need for a comprehensive programme for the protection of children by advocating a systems approach along a variety of lines and levels of action. He proposed that the interrelationship between the levels of action, viz. the child, family, community and the government must also be emphasised

\section{The South African Response: Child Labour Inter-Sectoral Group}

In October 1999 the commemoration of the first anniversary of the Child Labour Inter-Sectoral Group (CLIG) was held. The Basic Conditions of Employment Act 1997 and the Programme of Action on Child Labour elucidated the resolve of government and NGOs to eradicate the problem of child labour. The complexity of the problem of child labour necessitated a multi-sectoral approach, which resulted in the formation of CLIG in October 1998. CLIG is the forum under the auspices of the National Programme of Action for the Child (NPA) and co-ordinated by the Department of Labour, which also acts as the Secretariat. Regional and national networks were instituted to intensify the Programme of Action. Representation was comprised of government, non-governmental organisations, labour movements, business and community-based initiatives. Disciplines such as education, labour, health, justice and social welfare were, therefore, necessary partners in the Programme of Action. One of the major challenges confronting CLIG was the formation and maintenance of provincial and local structures for the implementation of intervention strategies. The formation of CLIG marked the long-awaited initiative to tackle the problem of child labour, with its primary goal being the eradication of this problem (Kettledas, 1999). The Programme of Action effectively addressed four aspects fundamental to its implementation, viz. policy, legislation, education and social mobilisation. These four interdependent aspects elucidated the measures to effect the Child Labour Programme of Action.

\section{Policy}

Central to the process of developing effective and appropriate policy on child labour is the identification of the gamut of precipitating factors. In this respect policy must unequivocally condemn the exploitation of children in hazardous environments. Notwithstanding the ethical condemnation of child labour, little will be achieved without policies addressing the root causes of child labour. Since child labour is concentrated in specifically disadvantaged regions, it is imperative to concentrate policy interventions in these areas. Constraints in the supply of education and health in these areas means that policy interventions should focus on the development of education and health infrastructure (Grootaert \& Patrinos, 1999). Since there is a strong correlation between child labour and poverty, reducing poverty will contribute more than any other intervention in the long term. Specifically programmes are needed to provide credit to poor household without collateral so that children would not have to be depended upon as insurance for income. The pioneering model of the Grameen Bank in Bangladesh has been replicated in many parts of the world. The model, based on social responsibility and peer pressure, provides an innovative approach to poverty reduction and ultimately child labour (Grootaert \& Patrinos, 1999). The parameters for operation and definitions guiding the interpretation and comprehension of the problem of child labour are provided by various statutes, including some of the following:

- The Constitution of South Africa 108 of 1996;

- $\quad$ The United Nations Convention on the Rights of the Child (1989);

- The African Charter on the Welfare and Rights of the Child;

- $\quad$ The International Labour Organisation (ILO) Minimum Age Convention (No. 138 of 1973); 
- $\quad$ Basic Conditions of Employment Act, 1997;

- $\quad$ The South African Schools Act, 1996;

- $\quad$ Child Care Act, 74 of 1983.

In keeping with the overall objective, the emphasis of the Programme of Action was the elimination of child labour in an organised, constructive manner. Effective legislation encompasses mechanisms to arrest the problem from escalating and to effect the urgent removal of children from hazardous situations. In the absence of reliable, accurate data, policy should focus on research to highlight both critical determinants of child labour and the effectiveness of the planned Programme of Action. The operationalisation of policy can be effective if there is a commitment and undertaking to:

- Develop a well co-ordinated National Programme of Action that is integral to the holistic development of children;

- Collate accurate statistics on children, which include birth and death registrations;

- Develop supportive programmes for families with child workers, so that they can be gradually reintegrated into mainstream society;

- Develop preventative programmes in the most impoverished communities to divert potential child workers;

- Establish an inter-sectoral and an inter-departmental committee to monitor the progress of the programme of action to eliminate child labour;

- Provide statistical information on the nature and extent of the problem of child labour in South Africa; this will facilitate the identification of the most abusive forms of child labour for priority attention.

The definition of child labour and the stipulation of the age limit are two critical factors on which consensus must be reached by all concerned in the war against child labour. The Programme of Action realising the need for consistency adapted the definition of child labour to read as follows:

work by children under 18 which is exploitative, hazardous or otherwise inappropriate for their age, detrimental to their schooling or social, physical, mental spiritual or moral development.

The term 'work' is not limited to work for gain, but includes chores or household activities if such work falls within this definition of child labour. Domestic work is possibly the most hidden form of child labour and girls are the most vulnerable victims of this practice. The status of girls in their families, communities and society requires special attention as they are much more vulnerable to sexual and other forms of exploitation. Since girls' work is largely determined by traditional/cultural practices, the amount of work done by them is not considered child labour (Sinha, 2000). Their vulnerability demands greater efforts to ensure their safety and protection. Steps to effect urgent removals and reintegrative programmes are a priority of this action programme and legislation and mechanisms to enforce it are critical. CLIG has been involved in extensive deliberation on setting age limits which are in accordance with other legislation, such as the Child Care Act. 


\section{Legislation}

In promulgating effective legislation, it is important to ensure that there is conformity with other national legislation and policies governing the welfare of children and education. Conformity with international standards is also important. Legislation should also take into account gender-specific needs and the effects of ethnic, cultural, religious and other forms of discrimination in child labour. Baker and Hinton (2001) argued that programmes failing to incorporate socio-cultural understanding in service provision were likely to fail to maximise their potential in offering children the opportunities to end the cycle of poverty. In South Africa, while the law prohibits employment of minors under the age of 15, it in fact does not protect children between the ages of 15 to 18. This omission has been the source of debate within government and NGOs. Legislation must also make allowance for enforcement, without which policy is ineffective. Legislation must also be consistent with enforcement capacity, which should be the responsibility of the police, not of inspectors of ministries of labour and social welfare (Grootaert \& Patrinos, 1999). The Enforcement Policy followed the Programme of Action on Child Labour (1999). This document focused on the necessary procedures to be undertaken, especially by the Department of Labour to maximise compliance with the chapter on child labour in the Basic Conditions of Employment Act (1997). The implications for enforcement are effective mechanisms to deal with violations and reintegration. This includes training and sensitising relevant personnel such as prosecutors, judges, police personnel, correctional services officers and social workers in child labour-related legislation.

Monitoring is another aspect of legislation that is necessary to ensure that violations are detected and addressed in good time. CLIG undertook training with various stakeholders and role players with the aim of equipping them with the relevant knowledge and skills required for monitoring. The aims of the training programme included the following:

- To understand the international and South African law on child labour;

- To obtain an overview of the South African Child Labour Action Programme;

- Identify and reach consensus on the various ways of detecting child labour;

- To acknowledge the dangers and disadvantages of child labour;

- To explore what action can be taken on child labour and the risks involved in the use of the different approaches;

- To consider the collective capacity to respond to child labour in South Africa;

- To consider ways to prioritise action.

The intention was largely that CLIG would be instrumental in devising measures to implement the Programme of Action and the Enforcement Policy. Representatives from the Department of Labour, child welfare organisations, academic institutions, Child Protection Services and members of NGOs formulated a plan of action where all participating members would be actively involved in the course of their work in identifying and bringing to the attention of the Child Protection Services (a specialised unit of the South African Police) any child who fits the criteria in terms of what constituted child labour. It was anticipated that trial cases would identify strategies for intervention and procedures to deal with all those concerned. It was, however, important to reiterate the complexity of the problem of child labour in order to link it to problems within the wider social context. The object of CLIG was, therefore, to collaborate with other role players such as Department of Social Development and the Department of Labour and Justice to agree on 
a programme of action that does not jeopardise the welfare of the child and the family, but instead create workable solutions to reintegrate both the family and the child within a more acceptable level of functioning by finding appropriate, alternative solutions. Implementation of policy and legislation depends on the availability and accessibility of resources. Both financial and human resources are critical requirements for success. Ideally, CLIG represented an integrated, holistic approach to child labour. In reality, this plan depended on adequate support, especially the allocation of resources (funding and personnel). Given the financial constraints of the various role players, CLIG's mission appears to be more an idealistic, philosophical stance rather than a pragmatic approach to the eradication of child labour.

All stakeholders have a role to play not only in identifying a plan of action, but also in the elimination of obstacles that threaten the effective implementation of the programme. Child labour, like most other social phenomena, straddles a range of services such as education, welfare, justice and safety and security. The urgent need for providing solutions lies not with one sector, although a driving force to propel the initiative is a necessity.

\section{Social Mobilisation}

Legislation is only one aspect of social change. Public education is universally agreed to be the most significant step in the eradication of child labour (Fyfe, 1989). Changing attitudes, raising awareness and education are important components in the attempt to eradicate child labour. To eradicate a problem of this magnitude the combined efforts of government, NGOs, business sector, civil society, trade unions and employers are necessary. The role of information gathering and dissemination in raising public awareness of the effects of child labour and exposing sectors of activities where it is prevalent should not be underestimated. There is an alarming degree of ignorance around the consequences of child labour and the disastrous effects of unsafe working conditions (Fyfe, 1989). Social mobilisation focuses on consciousness raising, creating awareness, initiating and promoting activism and action, organising, intervening and empowering society to take responsibility for eradicating child labour. Changes in perceptions can be facilitated through creating awareness with regard to the rights of the child, especially the right to basic education and to protection from exploitation. Awareness programmes should focus on sensitising parents, teachers, children, community members and employers, especially at the local level. Examples of successful public education programmes include the Centre of Concern for Child Labour in Bangkok, Thailand. This is an excellent example of an integrated approach to raising public awareness. The programme was established by the ecumenical association of Buddhists, Catholics and Protestants in 1981. The activities included research, dissemination, pressure groups and welfare services provision (Fyfe, 1989).

The lack of parental involvement in addressing the problem of child labour is notable. Strategies for increasing parental involvement are therefore necessary. Fear of intimidation or prosecution may prevent parents from becoming involved in seeking solutions to the problem of child labour. Parents, therefore, need to be conscientised about the effects of child labour and the child's right to education. Children's participation in the process of combating child labour is crucial. Their participation will ensure that interventions are designed to eliminate exploitative and hazardous labour identified by themselves as the persons affected by it. It would also be context specific, locally sustainable and child-centred (Woodhead, 1999). Provision should also be made to include children as a valuable resource in identifying their needs and a plan of action. An important consideration would therefore be to identify ways in which child workers themselves can inform and influence the development of appropriate policy. 


\section{Education}

Although education cannot be seen as the panacea for child labour, a more rigid educational programme will go a long way in reducing the high rates of child labour. The following are some suggestions for consideration by governments:

- Better provisions for early childhood education and care;

- Mobilisation for new resources;

- An end to exploitation of children for their labour;

- Democratic participation of civil society in education;

- Fair and regular salaries for teachers;

- Properly equipped classrooms and a supply of quality textbooks;

- Non-discrimination in the provision of education.

An integral aspect of the above includes psychosocial factors, which impinge on the families' ability to ensure that the child is provided with the necessary support to attend and remain in school as long as necessary. Given the history of South Africa, many of the above factors continue to impede the provision of equal educational opportunities for the majority of black people, more especially those in rural areas. Despite the overwhelming backlog, the government's commitment is evident in the promulgation of the South African Schools Act, 1996. It stipulates compulsory education for children between the ages of 7 to 15. In addition, the institution of a single syllabus and equitable funding criteria have been developed to overcome the backlog in the non-provision of resources. But despite these efforts, large-scale problems continue to keep millions of children out of school. Poverty, the increase in HIV/AIDS (and the resulting increase in the number of orphans who have to fend for themselves), violence, drug and alcohol abuse (of parents), and increasing family breakdown are some of the factors which prevent children from attending school. These circumstances emphasise the need for collaboration between the educational and welfare sectors. Children will continue to be excluded from the classroom until supportive structures and mechanisms are in place to address the psychosocial needs of children.

\section{CHALLENGES FOR SOCIAL WORK}

The mere fact that social workers interact and engage with communities on a micro, meso and macro level provide them with opportune situations for contributing to the eradication of child labour. Grass roots organisations allow for small-scale yet powerful ways in which public campaigning and education can occur. However, many grassroots organisations often tend to operate in isolation, reducing their opportunities for accessing and utilising resources effectively. Fyfe (1989) argued that such organisations provide not only opportunities for learning, but also for networking and sharing experiences. Many of these projects lend themselves to community participation, a value that is fundamental to community work. In the early 1960s the seminal work of Freire demonstrated a common commitment to community participation. Freire (1985) pioneered the concept of "conscientisation" - the awakening of the critical consciousness in poor people, which was envisaged as a way of breaking the culture of silence characteristic of poor communities. This approach is critical in the formulation of public awareness campaigns especially targeting parents and care givers. The approach lends itself to the development of community programmes owned and initiated by the community members themselves, a criterion for social work successful intervention. 
The welfare and well-being of children, one of the primary goals of social work, demands nothing less than zero tolerance toward any form of child labour that interferes with the personal and social development of the child (Grootaert \& Patrinos, 1999). The advocacy role of social workers provides ample opportunities for them to view this role as the foundation for further development of other intervention strategies. Central to this role is the child-centred approach, which offers children the opportunity to define their own needs and support as alluded to earlier in the article (Clinton \& Hodgson, 1997).

\section{CONCLUSION}

The growing resolve and commitment of the government to implement the United Nations Convention on the Rights of the Child (1989) is evident in the Programme of Action on Child Labour. There are, however, many systemic and practical constraints that threaten its effective implementation. The growing concern over the increasing commercialisation of sexual exploitation of children, especially females, deserves further emphasis. Central to the process of developing effective and appropriate policy on child labour is the identification of causative factors. Child labour is characteristic of developing countries where poverty is widespread. Child labour is both a consequence and cause of poverty (Department of Labour, 1998). The effects of colonialism, poverty and inequality create conditions for the perpetuation of the above practice. Unless governments acknowledge the violation of children's rights both nationally and internationally, the problem will continue to grow and ruin the moral fabric of society. There is an urgent need for countries to engage in bilateral discussions and agreements to curb the scourge of sexual exploitation that plagues society. The real need is to devise strategies which recognise the reality that in the foreseeable future many children will continue to work to support themselves and their families. An objective assessment with practical and realisable objectives is necessary in the short term to curb the increasing numbers of working children and in the long term to eradicate child labour as a social catastrophe.

\section{REFERENCES}

BAKER, R \& HINTON, R 2001. Approaches to children's work and rights in Nepal. The Annals of the American Academy of Political and Social Science. 575, May. 176-193.

CLINTON, J \& HODGSON, D 1997. In Cannan, C \& Warren, C. Social action with children and families: A community development approach to child and family welfare. London and New York: Routledge.

DELAP, E 2001. Economic and cultural forces in the child labour debate.: Evidence from Urban Bangladesh. The Journal of Development Studies. 37(4), 1-22.

DEPARTMENT OF LABOUR 1998. Programme of Action on Child Labour in South Africa

EL BAROMETER 2000. Child labour around the world. [http://globalmarch.org/cl-around-theworld/barometer-africa1.html]

FYFE, A 1989. Child labour. Cambridge: Polity Press.

KETTLEDAS, 1999. Labour market policy and labour market programmes. Unpublished Keynote address on the Commemoration of the $1^{\text {st }}$ Anniversary of the Child Labour Inter-Sectoral Group.

METI, RD; KRISHNASWAMY, A \& BHAT, A 2001. Problems of Female agricultural labourers in male and female headed households. The Indian Journal of Social Work, 62(1):29-45. 
MEYERS, WE. (ed) 1991. Protecting working children. London: Zed Books Ltd.

NARDINELLI, C 1990. Child labour and the industrial revolution. Indiana: University Press.

RODGERS, G \& STANDING, G (eds) 1981. Child work, poverty and underdevelopment. Geneva: International Labour Office.

SINHA, S 2000. In: REKHA, W The gender gap in basic education: NGOS as change agents. New Delhi: Sage.

UNITED NATIONS CONVENTION ON THE RIGHTS OF THE CHILD (1989).

UNICEF 1997. International Conference on Child Labour: Social mobilization for the elimination of child labour. Oslo, 27-30 October.

WHITE, B 1999. Defining the intolerable: Child work, global standards and cultural relativism. Childhood. 6(1):133-144.

WOODHEAD, M 1999. Combatting child labour: Listen to what the children are saying. Childhood. 6(1):27-39.

\section{LEGISLATION AND OTHER LEGAL FRAMEWORKS CONSULTED:}

The Constitution of South Africa 108 of 1996.

The United Nations Convention on the Rights of the Child (1989).

The African Charter on the Welfare and Rights of the Child.

The International Labour Organisation (ILO) Minimum Age Convention (No 138 of 1973).

Basic Conditions of Employment Act, 1997.

The South African Schools Act, 1996.

Child Care Act, 74 of 1983. 